\title{
A conversation with Bruce Spiegelman
}

$\mathrm{M}$ ore than almost any other scientist in the field of obesity and metabolism research, the work of Bruce Spiegelman (Figure 1), from the Dana-Farber Cancer Institute and Harvard Medical School, has informed potential targets for drug discovery that could burn fat and even turn fat into muscle. He was the first to suggest that inflammation underscores insulin resistance, and also the first to find the key regulator of adipogenesis, PPAR- $\gamma$. The full interview, with more stories and his tips for working with journal editors, can be seen on the JCI website at http://www.jci.org/kiosk/cgm.

JCI: Can you start by telling us about your upbringing?

Spiegelman: I was brought up outside New York on Long Island in a town called Massapequa, famous as the home of Jerry Seinfeld and the Baldwin brothers. My parents didn't go to college, but they felt it was important for my brother and me to go to college. When I was a kid growing up, I always loved the outdoors - fish, bugs, birds, anything having to do with nature and living systems. I was a pretty good student when I was growing up, but it was when I went to college that I applied myself for the first time and really got interested in science. I began to focus more and more academically; and I found, amazingly enough, that the more I put into it, the more I got out of it. The harder I studied, the more interesting it seemed. That had never occurred to me before. I was a biology major, and like a lot of biology majors, I really dreaded taking chemistry. Certainly from taking high school chemistry, I had demonstrated absolutely no particular aptitude. But then again, I'd never actually done any work. When I was in organic chemistry I was very intimidated at first, but I found I really enjoyed it and I was good at it!

JCI: You actually authored a scientific paper while you were in college.

Spiegelman: I had a first author paper when I was an undergraduate but I don't think it was a particularly significant paper. Again, it was more about building confidence. But I think it illustrated some degree of raw talent - at least that I could get very invested in a scientific problem. At William \& Mary, the pressure was not on the professors to publish and the professor I worked with hadn't published anything in quite a few years. The fact that my work was going to be published gave me confidence, probably more than was appropriate for the importance of the work.

JCI: So what motivated you to pursue a $\mathrm{PhD}$, which you did at Princeton with Marc Kirschner?

Spiegelman: The major reason I went to Princeton is because my undergraduate mentor, who was not really in the world of research, had heard of [the biochemist] Arthur Pardee, and Art Pardee was at Princeton. A lot of people now don't recognize it, but in the '70s Princeton had one of the best biochemistry departments in the world. Besides Art, who eventually became a friend, Marc Kirschner, Bruce Alberts, Uli Laemmli, Hal Weintraub, and Arnie Levine were all there, young and active. For this one period in the '70s, Princeton had a phenomenal biochemistry department. Other students there at the same time as myself were Art Levinson, who is now the chairman of the board of Apple and Genentech, as well as Elaine Fuchs, Don Cleveland, and Keith Yamamoto. At the time, of course I didn't realize how good it was, because I was doing a $\mathrm{PhD}$ and these were the only real scientists I knew. Later, I realized that was a very good crowd to be surrounded by. JCI: What was your work actually focused on while you were doing your $\mathrm{PhD}$ ?

Spiegelman: It was focused on the control of microtubule assembly. Marc's lab was doing protein biochemistry of the microtubule, trying to understand the way they assemble. Most of the work in the lab was in vitro, taking microtubules apart, understanding the different protein factors. I was interested in what controlled the assembly in cells, and so I published a few papers related to regulation of microtubule assembly in a cellular context by nucleotides and microtubule organizing centers.

JCI: You moved on to MIT to do your postdoc. Was that a natural extension of your work at Princeton?

Spiegelman: Not at all. I had become interested, even before I worked in Marc's lab, in how one cellular phenotype switches to another phenotype. At the end of my time in Marc's lab, I looked into cytoskeletal reorganization during neural differentiation. Howard Green had developed two new systems for mammalian cell differentiation that were exceptionally faithful to in vivo development. It's still true that they are two of the most faithful culture systems - fat cell differentiation and skin cell differentiation. I didn't care which one I worked on. In fact, I wrote my fellowship application on skin cell differentiation. Turns out that $80 \%$ of Howard's lab was working on skin cell differentiation. When I arrived, the postdoc that Howard thought that I would replace was still there working on skin. Somebody he had working on fat had left and he didn't have many people working on fat cell differentiation, so Howard asked me if I was interested. I was interested in cell fate switching, which cell at that point didn't matter much to me. JCI: Was it this period that then drove your inspiration to work on metabolism?

Spiegelman: Neither Howard nor anybody in his group was particularly interested in metabolic disease. So I began to teach myself how fat cells and fat cell biology fit into the broader program of metabolism. I also have to credit Jeff Flier and Ron Kahn, two other faculty at Harvard, who befriended me. They came to an interest in fat cell biology from the metabolic disease angle, and I really learned a lot from both of them.

The goal of my newly established laboratory was to understand the transcriptional regulators of switches in cell fate in the adipose lineage. Our work in metabolism often had its origin in the important regulatory molecules that we found while looking into the basic biology of how a fat cell stores lipid, how it switches fate, and how it makes mitochondria in the case of brown fat. A lot of the molecules we discovered came from basic studies of cell fate and regulatory pathways in differentiation.

JCI: I read from a previous interview you gave that one of your most fulfilling moments was staring down in a microscope and seeing fibroblasts that had turned into fat cells. You were on the cusp of figuring out PPAR- $\gamma$.

Spiegelman: That was the "jihad" that the lab had been on since its founding trying to find the molecule that switched preadipose cells to adipose cells! We started off cloning fat cell genes, then we cloned fat cell promoters and enhancers, then we identified the regulatory elements, then we identified the binding protein. Eventually, we could take fibroblasts, put in a retroviral vector expressing PPAR- $\gamma$, look down the microscope, and watch cells turn into 


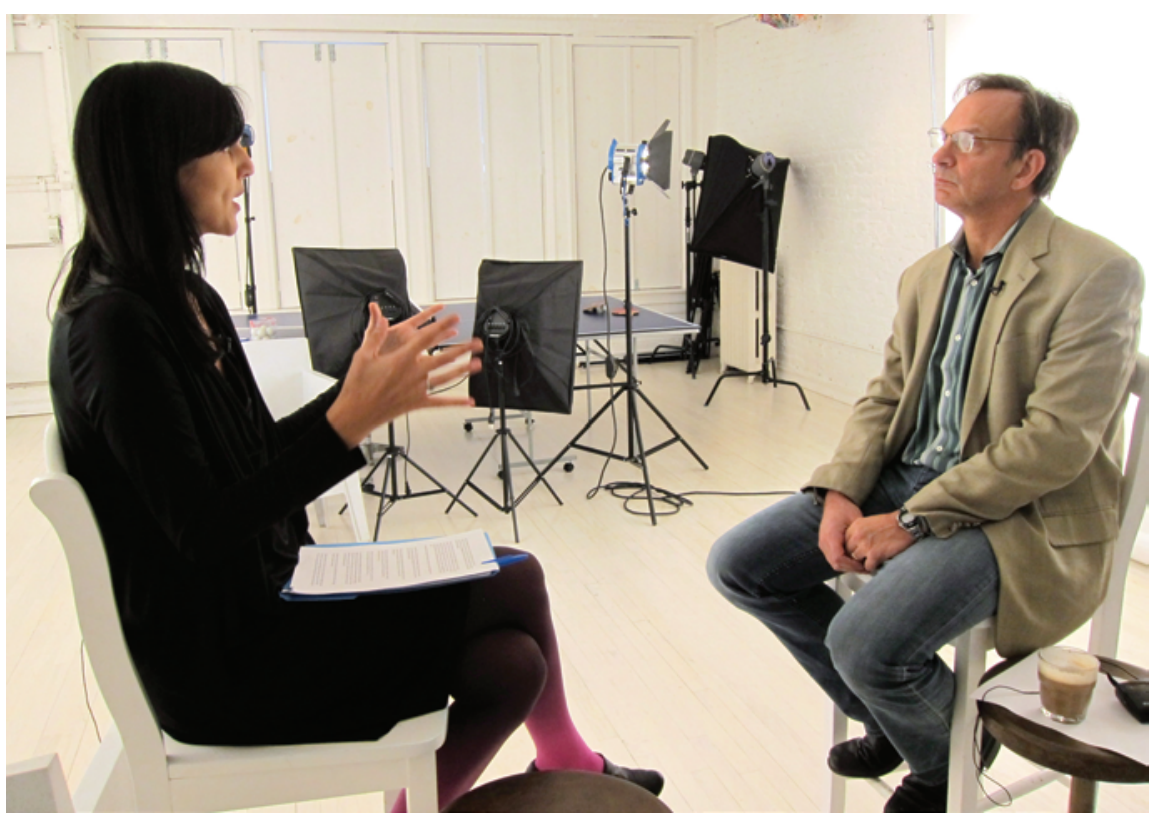

Figure 1

Ushma Neill interviews Bruce Spiegelman on March 11, 2013, in New York City. Image credit: Semyon Maltsev.

fat. That was extremely exciting, very gratifying, and a turning point in my scientific career. Those studies by Peter Tontonoz also represented a turning point for my laboratory. We picked a really hard problem and solved it. It meant a lot in terms of the recognition the lab got, and meant a lot in terms of my own self-confidence.

JCI: The mainstream media often reports on your studies with headlines like, "Harvard scientist discovers that we don't need to exercise any more." I'm sure this must have alternately thrilled and frustrated you.

Spiegelman: Well, you've sort of hit a touchy point with me. It turns serious scientific efforts into something quite crass. Is there a therapeutic potential in these pathways and particularly in the development of brown and beige fat? Absolutely! But the goal is not to develop a pill so that ordinary healthy people need not exercise; many people can't exercise, like those with paraplegia, bed-ridden patients, and the elderly. For people who may not be capable of exercising enough to provide good metabolic health, it would be fantastic to have a medical approach. And as people get older they usually get sarcopenia [loss of muscle mass] and osteopenia [loss of bone mass]. The fact is, if grandma and grandpa hit the gym for 90 minutes a day pumping iron, it is conceivable that we could arrest their osteopenia and sarcopenia. But it's not going to hap- pen, and so having a medical approach to these things makes a lot of sense.

JCI: Beyond the targets that you've sought within white fat and brown fat, you've also developed specific mouse models that turn into "Mighty Mouse." Will there ever be a medical approach that the Lance Armstrongs of the world could take in pill form? Spiegelman: I am very confident that we can capture some of the benefit of exercise in molecular form. Exercise is not magic. It's a series of chemical reactions involving muscle. We have already discovered iri$\sin$, and we have another target that we're working hard on. The benefit of exercise, like most things in nature, will eventually come to down to chemistry and biochemical reactions. I think we, and others, are capable of capturing them. We could find so many uses for them that have nothing to do with the Lance Armstrongs of the world; and I just refuse to be limited by that kind of worry. If your aunt or your brother had ALS or muscular dystrophy, you wouldn't worry about whether Lance Armstrong and guys like him would abuse a new therapy.

JCI: You yourself are not particularly lazy and don't seem to need any pills to help with keeping you active. How is it that you have had 30 Cell papers, 11 Science papers, 16 Nature papers, and 11 in the JCI? There can't be that much more low-hanging fruit for you to find.
Spiegelman: I disagree. There is a lot of low-hanging fruit out there! When we discovered PGC-1 $\alpha$, people weren't even looking for something like that. But there must be many more dynamic molecules that can switch cell biology - that can switch cell physiology - that have yet to be discovered. We talk about exercise but almost nothing is known about what gives the benefit of exercise to your heart and your liver and your brain. Right there, that's 30 years worth of work that needs doing.

JCI: You have either had an excellent eye for students or an enormous amount of luck, as you've had students that are the academic superstars within this field from Gökhan Hotamisligil to Peter Tontonoz, Evan Rosen, and Pere Puigserver. Also, I've been to a rather raucous Spiegelman lab party.

Spiegelman: I believe you were the one filling my glass.

JCI: Well, other than fostering a sense of fun within the lab, what's your secret to getting the most out of these students?

Spiegelman: You can't make people have talent, sadly. An effective PI has to have an eye for talent. What I am usually looking for is people who are exceptionally passionate about science. Will they really love it and want to spend their life doing this? I also view it as my job to get people ready for the next step. So I can be a bit critical in lab meetings, and I am adamant about my students taking their lab presentations very seriously. I also meet with every single scientist in the lab at least once every two weeks, one-on-one in my office. And we usually talk about science, but we also discuss career stuff. Sometimes we even talk about their personal situation, if they want to tell me about it, especially as it affects their professional life. I think it comes down to caring about people and caring about their careers. I love most of the people who've been in my laboratory. I feel very paternally toward them and I am proud of them.

JCI: If you could change careers now, what would you do?

Spiegelman: I'd probably be a fishing captain. I love the water and I love the outdoors. I'm a very avid fisherman, and I can outfish a lot of professional captains. And so in the ideal world, I actually wouldn't mind being a charter captain. But being a fishing captain, it is not so easy to make a living. So I guess I'll stick to science.

\section{Ushma S. Neill}

